\title{
Sexual behaviour of ewes with clover disease treated repeatedly with oestradiol benzoate or testosterone propionate after ovariectomy
}

\author{
N. R. Adams \\ CSIRO Division of Animal Production, Private Bag, Wembley, Western Australia 6014
}

\begin{abstract}
Summary. Ovariectomized ewes, 14 with permanent clover disease infertility (affected ewes) and 14 controls, were injected daily with $40 \mu \mathrm{g}$ oestradiol benzoate for 12 days, and run with 2 rams fitted with marking crayons. The control ewes were mated sooner $(P<0.05)$ but both groups became refractory at a similar rate. In a second experiment, 20 similar affected ewes and 19 controls were injected daily with $5 \mathrm{mg}$ testosterone propionate for 31 days and observed daily for $50 \mathrm{~min}$ with rams. Affected ewes again were slower to show female behaviour $(P<0.05)$ but faster $(P<0.05)$ to show aggression against the rams and other ewes. Over the 31 days, the incidence of female sexual behaviour declined at a similar rate in affected and control ewes. When examined in individual pen tests with oestrous ewes on Day 28 , affected ewes showed more male-like courting behaviour than did controls $(P<0.05)$. The changes in behaviour are too slight to account for the infertility but they do support the hypothesis that phyto-oestrogens can act on the ewe by some of the pathways of sexual differentiation, even after puberty.
\end{abstract}

\section{Introduction}

Ewes which have grazed oestrogenic clover pastures for several years can develop permanent infertility (Schinckel, 1948) as part of the syndrome called clover disease. Such ewes are infertile because of impaired transport of spermatozoa through the cervix (Lightfoot, Croker \& Neil, 1967). This cervical dysfunction is associated with a low spinnbarkeit of the cervical mucus resulting from an abnormal responsiveness to endogenous oestrogen (Adams, 1979) and is accompanied by metaplasia of the cervix so that histologically it resembles the uterus (Adams, 1976). Oestrogen has not been reported to cause this type of histological change in adult females of other species, although analogous changes may be caused by oestrogen during the period of organogenesis (Forsberg, 1969).

Permanently affected ewes exhibit slightly less female sexual behaviour than do controls after a single dose of oestradiol benzoate (Adams, 1978). The present study was carried out to see whether the behavioural responses of affected ewes to repeated treatment with oestradiol benzoate or testosterone propionate were altered. Some of these results have been referred to previously (Adams, 1981).

\section{Materials and Methods}

Two studies were carried out on 8-year-old Merino ewes which had been ovariectomized for at least 1 year. Half of the ewes had grazed a highly oestrogenic pasture of Yarloop subterranean clover for 3 years and only $11 \%$ had lambed after the last year of exposure. The control ewes originated from 
the same group, but had grazed non-oestrogenic pasture during this period and were of normal fertility $(76 \%$ lambing). Subsequently all the ewes were run together on non-oestrogenic pasture for 4 years.

The effects of $40 \mu \mathrm{g}$ oestradiol benzoate injected i.m. in oil were studied in 14 affected ewes and 14 controls which were injected daily for 12 days. The ewes were run with 2 vasectomized rams fitted with a harness and marking crayon. Each day the colour of the crayon was changed and the ewes marked were recorded.

The effects of daily i.m. injection for 31 days with $5 \mathrm{mg}$ testosterone propionate in oil were studied in other ewes from the same flock (19 control and 20 affected ewes). The ewes were individually identified with a large number painted on the side, and were run in 2 large pens. Each day, 2 active rams were run in each pen for $50 \mathrm{~min}$ and the sheep were observed from seclusion. The number of times each ewe showed female sexual behaviour (standing to be mounted, soliciting the ram, looking over the shoulder at the ram and tail fanning; Banks, 1964) was recorded. The frequency was also recorded for bunting of rams and other ewes, and rubbing the side of the face or the horn buds on pen divisions or on other ewes in a manner similar to the rubbing and bushthreshing behaviour described by Grubb \& Jewell (1973). The relative incidence of masculine sexual behaviour (ano-genital sniffing, Flehmen reaction, and courting by pawing or nudging; Banks, 1964) was determined by observing the ewes individually in a pen with 3 other oestrous ewes for 7 min on Days 14, 21 and 28 of treatment.

Data were analysed statistically by the $t$ test or, if the variances were not homogeneous, by Wilcoxon's two-sample rank test.

\section{Results}

\section{Oestradiol benzoate}

All of the ewes displayed oestrus, but the onset of mating was earlier and less variable in the control than in the affected ewes $(2.5 \pm 0.3$ compared with $4 \cdot 0 \pm 2.5$ days, $P<0.05$ Wilcoxon's test). The control and affected ewes continued to be marked by the ram for a similar time $(5 \cdot 1 \pm 0 \cdot 8$ and $4.6 \pm 0.8$ days, respectively) and the mean for the last day on which matings occurred was not significantly different for the two groups $(8 \cdot 1 \pm 0 \cdot 7$ and $8.8 \pm 0 \cdot 7$ days $)$.

\section{Testosterone propionate}

As shown in Table 1, the affected ewes treated with testosterone propionate took longer to stand and be mated by the ram $(P<0.05$, Wilcoxon's test) and showed less soliciting behaviour in the first week of study (Table $1 ; P<0.05$ ). The number of ewes showing soliciting behaviour and the

Table 1. Female sexual behaviour in a group of 19 clover-affected and 20 control ovariectomized ewes during the first 7 days of daily treatment with $5 \mathrm{mg}$ testosterone propionate

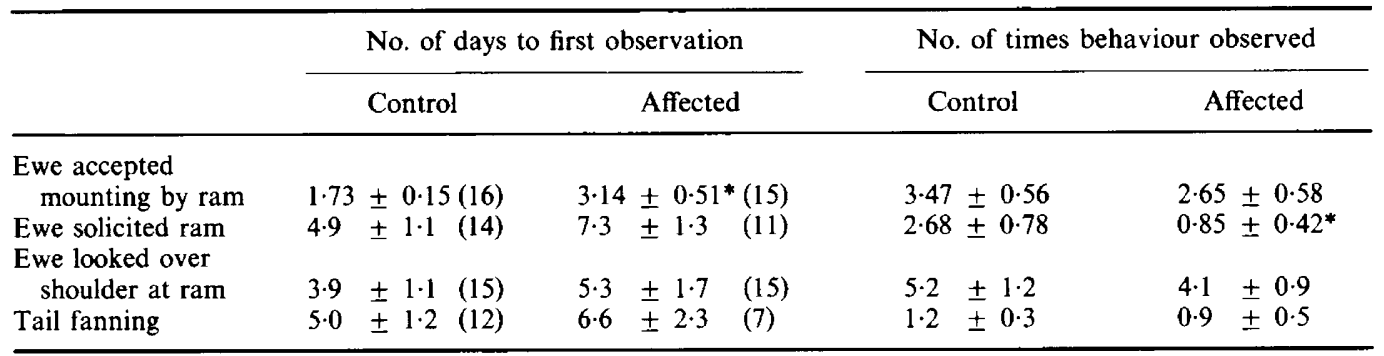

Values are mean \pm s.e.m. Figures in parentheses indicate the number of ewes showing this behaviour.

* Value significantly different from control, $P<0.05$. 
number which stood to be mounted by the ram declined over the 5 -week treatment period (Text-fig. 1). The affected and control ewes did not differ from one another in the rate of decline in responses with continued treatment.
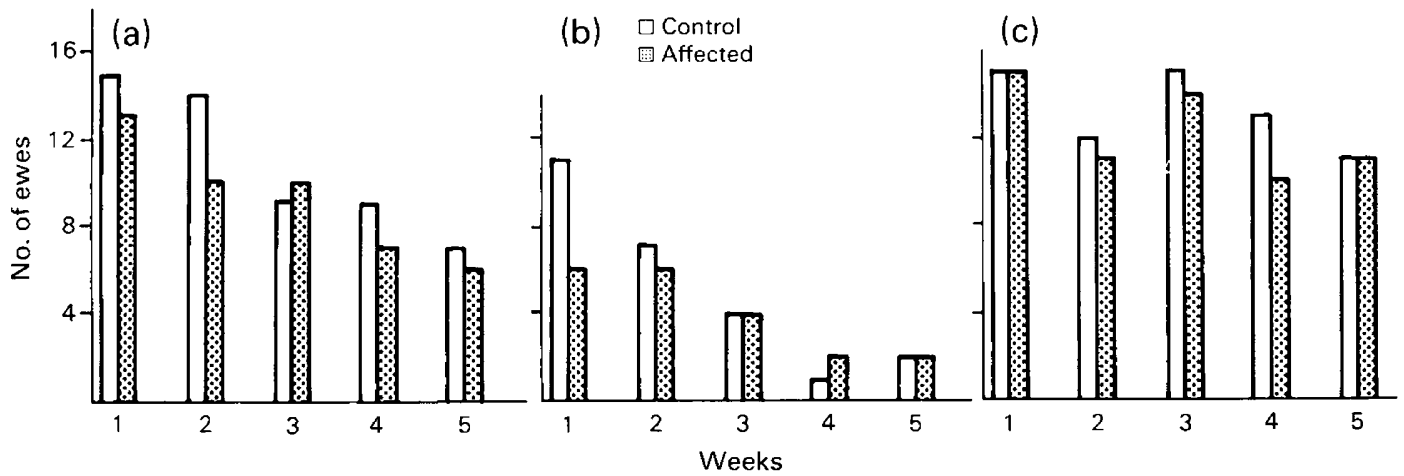

Text-fig. 1. Total numbers out of 19 control or 20 affected ewes which (a) accepted mounting, (b) solicited, and (c) looked over their shoulder, in each week, during daily 50 -min observation periods.

Some ewes challenged and head-bunted the rams, and sometimes other ewes as well. Such aggressive behaviour was observed earlier $(P<0.05)$ in the affected (mean onset $15.7 \pm 1.6$ days) than in the control $(21 \cdot 8 \pm 2 \cdot 1$ days $)$ ewes, and did not appear to be related to female sexual behaviour. Ewes also rubbed the poll or the side of the face on pen divisions or on other ewes; this behaviour was also exhibited sooner by affected ewes than by controls $(6 \cdot 0 \pm 1.0$ compared with $10.8 \pm 1.4$ days, $P<0.05$ ).

When ewes were tested for male sexual behaviour, the total number of ewes showing courting behaviour increased after the first test (Table $2 ; 12$ on Day 14 compared with $21 ; \chi_{1}^{2}=4 \cdot 25, P<$ $0 \cdot 05)$. In each test, affected ewes showed more courting behaviour than did controls and, by Day 28 , this difference was statistically significant (Wilcoxon's test, $P<0.05$; Table 2). There was no significant difference between groups or tests in Flehmen behaviour or in ano-genital sniffing.

Only 2 ewes (both controls) were observed to mount other ewes throughout the study.

Table 2. Number of times that 19 control and 20 clover-affected ovariectomized ewes injected daily with $5 \mathrm{mg}$ testosterone propionate showed male behaviour during pen tests

\begin{tabular}{|c|c|c|c|c|c|c|}
\hline & \multicolumn{2}{|c|}{ Day 14} & \multicolumn{2}{|c|}{ Day 21} & \multicolumn{2}{|c|}{ Day 28} \\
\hline & Control & Affected & Control & Affected & Control & Affected \\
\hline Courting & $8 \cdot 8 \underset{(6)}{ \pm} 5 \cdot 1$ & $11 \cdot 7 \underset{(6)}{ \pm} 4 \cdot 3$ & 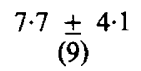 & ${ }_{(12)}^{10 \cdot 8}{ }^{3 \cdot 0}$ & $6 \cdot 4 \underset{(7)}{ \pm} 4 \cdot 5$ & $14.0 \pm{ }_{(11)} 2 \cdot 8^{*}$ \\
\hline Flehmen & $2.5 \underset{(6)}{ \pm} 0.8$ & $1.6 \pm 0.4$ & $2 \cdot 3 \pm \frac{ \pm}{(4)} 1 \cdot 3$ & $2 \cdot 9_{(8)}^{ \pm} 1 \cdot 1$ & $1 \cdot 2 \underset{(6)}{ \pm} 0 \cdot 2$ & $1 \cdot 4 \frac{ \pm}{(5)} 0 \cdot 2$ \\
\hline $\begin{array}{l}\text { Ano-genital } \\
\text { sniffing }\end{array}$ & $\begin{array}{c}3.5 \pm 0.5 \\
(13)\end{array}$ & ${ }_{(11)}^{4 \cdot 1 \pm 0.9}$ & ${ }_{(14)}^{3.7}$ & $\begin{array}{c}3 \cdot 6 \pm 0.6 \\
(16)\end{array}$ & $3.6 \underset{(14)}{ \pm 0.7}$ & $4 \cdot{\underset{(12)}{ \pm}}^{ \pm} 1 \cdot 6$ \\
\hline
\end{tabular}

Values are mean \pm s.e.m. for the no. (in parentheses) of ewes showing the behaviour.

* Significantly different from control, $P<0.05$.

\section{Discussion}

The behaviour of the ewes in the present study was consistent with that observed previously in ewes treated with oestradiol benzoate (Adams, 1978) or testosterone propionate (Signoret, 1975). Adams (1978) showed that mating and soliciting behaviours in oestradiol-treated ewes were more dose- 
dependent than was tail fanning or looking over the shoulder, and in the present study the former behavioural features were also the most sensitive indicators of a difference between affected and control ewes treated with testosterone propionate. In the previous study on ovariectomized ewes (Adams, 1978), delayed onset or reduced incidence of female sexual behaviour was observed in clover-affected ewes given a single injection of oestradiol benzoate after treatment with progesterone for 10 days. The similar delay in onset of female mating behaviour in affected ewes given oestradiol benzoate alone in the present study indicates that the impairment results from an altered responsiveness to the oestradiol, and not from a reduced effectiveness of progesterone priming.

It is unlikely that the relatively minor changes in sexual behaviour in affected ewes have any direct bearing on the infertility. However, the nature of the changes does provide an insight into other changes which have been observed in permanently affected ewes. The uterine-like histological metaplasia of the cervix in affected ewes is best interpreted as an oestrogen-dependent differentiation (Lightfoot \& Adams, 1979). In addition, ovariectomized affected ewes have increased protein and glycoprotein synthesis in the uterus and cervix and increased epithelial cell keratinization in the vagina, in the absence of any hormonal stimulation (Tang \& Adams, 1981). Similar changes have been reported in female rodents treated neonatally (i.e. at the time of sexual differentiation) with oestrogen or testosterone (Kohrman \& Greenberg, 1968; Takasugi \& Kamishima, 1973). Such animals also have decreased female sexual behaviour and increased male behaviour (Phoenix, Goy, Gerall \& Young, 1959; Gorski, 1973; Whalen \& Etgen, 1978) and increased aggressive behaviour (Bronson \& Desjardins, 1970) when stimulated with hormonal steroids during adult life. The parallel between the results of the present study and the organizational effects of neonatal oestrogen or testosterone on sexual behaviour in rodents is obvious. A similar parallel between the organizational effects of steroids and changes in permanently infertile ewes is the inability of ovariectomized affected ewes to release a surge of LH in response to oestradiol (Findlay et al., 1973).

The ewes in the present study and those of Adams (1976) and Tang \& Adams (1981) had never been exposed to phyto-oestrogens until after puberty. Thus, the permanent effects of phytooestrogens on the ewe mimic at least some of the changes caused by hormonal steroids during differentiation, even though the phyto-oestrogens are administered outside the normal period of organogenesis. It is not known whether steroidal oestrogens given to the adult ewe over a long period can also induce permanent differentiation.

I thank the West Australian Department of Agriculture for making the ewes available and M. R. Sanders for assistance

\section{References}

Adams, N.R. (1976) Pathological changes in the tissues of infertile ewes with clover disease. J. comp. Path. 86, 29-35.

Adams, N.R. (1978) Sexual behaviour responses of the ovariectomized ewe to oestradiol benzoate, and their persistent reduction after exposure to phyto-oestrogens. J. Reprod. Fert. 53, 203-208.

Adams, N.R. (1979) Altered response of cervical and vaginal epithelia to oestradiol benzoate in ewes after prolonged exposure to oestrogenic pasture. J. Reprod. Fert. 56, 611-613.

Adams, N.R. (1981) A changed responsiveness to oestrogen in ewes with clover disease. J. Reprod. Fert., Suppl. 30, 223-230.
Banks, E.M. (1964) Some aspects of sexual behaviour in domestic sheep, Ovis aries. Behaviour 23, 249-279.

Bronson, F.H. \& Desjardins, C. (1970) Neonatal androgen administration and adult aggressiveness in female mice. Gen. comp. Endocr. 15, 320-325.

Findlay, J.K., Buckmaster, J.M., Chamley, W.A., Cumming, I.A., Hearnshaw, H. \& Goding, J.R. (1973) Release of luteinizing hormone by oestradiol-17 $\beta$ and a gonadotrophin-releasing hormone in ewes affected with clover disease. Neuroendocrinology 11, 57-66.

Forsberg, J.G. (1969) The development of atypical epithelium in the mouse uterine cervix and vaginal fornix after neonatal oestradiol treatment. Br.J. exp. Path. 50, 187-195. 
Gorski, R.A. (1973) Perinatal effects of sex steroids on brain development and function. Prog. Brain Res. 39, 149-163.

Grubb, P. \& Jewell, P.A. (1973) The rut and the occurrence of oestrus in the Soay sheep on St Kilda. $J$. Reprod. Fert., Suppl. 19, 491-502.

Kohrman, A.F. \& Greenberg, R.E. (1968) Permanent effects of estradiol on cellular metabolism of the developing mouse vagina. Devl Biol. 18, 632-650.

Lightfoot, R.J. \& Adams, N.R. (1979) Changes in cervical histology in ewes following prolonged grazing on oestrogenic subterranean clover. J. comp. Path. 89, 367-373.

Lightfoot, R.J., Croker, K.P. \& Neil, H.G. (1967) Failure of sperm transport in relation to ewe infertility following prolonged grazing on oestrogenic pastures. Aust. J. Agric. Res. 18, 755-765.

Phoenix, C.H., Goy, R.W., Gerall, A.A. \& Young, W.C. (1959) Organizing action of prenatally administered testosterone propionate on the tissues mediating mating behavior in the female guinea pig. Endocrinology 65, 369-382.
Schinckel, P.G. (1948) Infertility in ewes grazing subterranean clover pastures. Observations in breeding behaviour following transfer to "sound" country. Aust. vet. J. 24, 289-294.

Signoret, J.P. (1975) Effects of oestrogen and androgen on the sexual behaviour responses of the ovariectomized ewe. Psychoneuroendocrinology 1, 179-184.

Takasugi, N. \& Kamishima, Y. (1973) Development of vaginal epithelium showing irreversible proliferation and cornification in neonatally estrogenized mice: an electron microscope study. Develop. Growth \& Different. 15, 127-140.

Tang, B.Y. \& Adams, N.R. (1981) Oestrogen receptors and metabolic activity in the genital tract of ovariectomized ewes with permanent infertility caused by exposure to phyto-oestrogens. J. Endocr. 89, 365-370.

Whalen, R.E. \& Etgen, A.M. (1978) Masculinization and defeminization induced in female hamsters by neonatal treatment with estradiol benzoate and RU2858. Horm. \& Behav. 10, 170-177.

Received 23 August 1982 